\title{
THE CONDITIONS FOR FOREIGNERS TO WORK IN TURKEY WITHOUT BEING SUBJECT TO SOCIAL INSURANCE
}

\author{
DOI: 10.17261/Pressacademia.2018.1007 \\ RJBM- V.5-ISS.4-2018(1)-p.238-244
}

\section{Mahmut Kabakci}

Istanbul Technical University, Faculty of Management, Department of Management Engineering, Macka Campus, İstanbul, Turkey. mkabakci@itu.edu.tr, ORCID: 0000-0003-1261-8310

Date Received: October 17, 2018

Date Accepted: December 19, 2018

To cite this document

Kabakcl, M. (2018). The conditions for foreigners to work in Turkey without being subject to social insurance. Research Journal of Business and Management (RJBM), V.5(4), p.238-244.

Permemant link to this document: $\underline{\text { http://doi.org/10.17261/Pressacademia.2018.1007 }}$

Copyright: Published by PressAcademia and limited licenced re-use rights only.

\section{ABSTRACT}

Purpose- The status of persons residing in a foreign country and working in Turkey for a temporary period will be examined in terms of social insurance law.

Methodology- Law numbered 5510 and the circulars of Social Security Institution will be assessed in the light of Court of Cassation's judgment and doctrine.

Findings- The fact that element of temporariness is limited to 3-month period in the regulations constitutes a burden beyond the measure that exceeds the purpose of social security in long-term assignments despite its temporary nature in practice.

Conclusion- Persons who continue to be insured in the country of which they are citizens should not be adapted to the Turkish social insurance system irrelevant of the length of temporary assignment period.

Keywords: Social insurance, insured, social security of foreigners, temporary assignment.

JEL Codes: K31, K41, J41

\section{INTRODUCTION}

Each country adopts different principles that restrict foreigners while regulating rights and obligations related to their citizens. According to article 16 of the Constitution titled situation of foreigners, "Basic rights and freedoms for foreigners may be restricted by law in accordance with international law". However regardless of citizenship, humanity's need for assurance against social risks such as disease, unemployment, old age is common; therefore, from the legal aspect social security is the area that should not be regulated different for foreigners (Tuncay/ Ekmekçi, 2017: 298). ILO Convention concerning Equality of Treatment of Nationals and Non-Nationals in Social Security dated 1962 numbered 118 which Turkey is a party to emphasize the obligation of states to provide a minimum level of assurance against social risks to foreigners with dignity on an equal basis with their citizens. The principle of territoriality which is valid in social security law, finds its basis with the Convention No. 118 within the frame of international law and prohibits states to a certain extent to exclude foreigners from the social security system or to grant foreigners worse rights than its citizens.

As in other countries, pursuant to the principle of territoriality, foreigners working in Turkey either dependently or independently are subject to the same legislation as Turkish citizens, without prejudice to the provisions of the bilateral social security agreements signed with 28 countries (For the full list of countries with which Turkey has signed bilateral social security agreement see http://www.sgk.gov.tr/wps/portal/sgk/tr/emekli/yurtdisi_islemler/sosyal_guvenlik_sozlesmeleri). As in the case of temporarily assignment of the employees by the enterprise established in foreign countries to its subsidiaries in Turkey or to 
thirds parties, in case of foreign citizen's working in Turkey is temporary, adapting him/ her into Turkish social security system results against him/ her due to the reasons of double payment of contributions, non-transfer of paid contributions between the countries. At this point, the differential criterion for the different treatment is whether the temporarily assigned employee's social insurance continues in the consignor country.

The subject of this study is the conditions under which foreign nationals who work in Turkey subjected to social insurance fall outside the scope of Turkish social insurance scheme. Regarding the subject, international law principals concerning the legal status of foreigners in social security law and its application in Turkish law will be examined first and the conditions for foreigners to be able to work without being insured in Turkey as an exception of the principle of territoriality in social security law will be presented.

\section{PRINCIPLES OF INTERNATIONAL LAW AND TURKISH LEGISLATION ON THE SOCIAL SECURITY OF FOREIGNERS}

\subsection{Prohibition of Different Treatment with the Justification of Citizenship in the Field of Social Security}

The first convention of the International Labour Organization in the field of social security is the Social Security Minimum Standards Convention dated 28.06.1952. The other fundamental convention which is the continuation of the aforementioned convention and directly related to our subject is the Convention concerning Equality of Treatment of Nationals and NonNationals in Social Security dated 28.06.1962. Both of these conventions to which Turkey is a party, entered into force with the ratification act dated 29.07.1971 numbered 1453 (OG. 10.08.1971, 13922). In relation to our subject, the essence of the Convention No. 118 is the equal treatment of the nationals of any other member states for which the Convention is in force with its own nationals both as regards coverage and as regards the right to benefits, in respect of every branch of social security for which it has accepted the obligations of the Convention (art. 3).

In the Convention after the social risks as medical care, sickness benefit, maternity benefit, invalidity benefit, old-age benefit, survivors' benefit, employment injury benefit, unemployment benefit and family benefit were listed as in ILO Convention No. 112 , member states were entitled to limit the obligation of equal treatment to one or more of the social risks listed here (art. 2). There is an exception to limitation regarding death benefits. According to this, in case of death benefits, it is sufficient for the country in which the foreigner is a national to be a party to the Convention No. 118 in respect of equal treatment, a limitation is prohibited in this regard. Equality of treatment as regards the grant of benefits cannot be accorded with any condition of residence (art. 4). However, this principle is not unconditional. Firstly, provided that equality of treatment in respect of the benefits of a specified branch of social security may be made conditional on residence in case of nationals of any Member states the legislation of which make the grant of benefits under that branch conditional on residence on its territory. The Convention No. 118 does not impose any obligation to provide a more advantageous situation for foreigners than nationals. Secondly, for the grant of the benefits other than medical care, sickness benefit, employment injury benefit and family benefit that funded directly by the insured persons and their employer or subjected to condition for insured to have worked for a certain period of time,

6 months before the request for assistance for maternity and unemployment benefits,

5 years of invalidity from the date of the request for invalidity benefits;

10 years after the age of 18 years for old age benefits, five years of this decade can be sought to be just before the request for assistance.

With the help of these brief explanations, it should be said that the foreignness in the field of social security cannot be a ground for different treatment from the citizens except for some exceptions, and that every foreigner who fulfils the conditions laid down in the legislation has the right and obligation to be insured.

\subsection{Work Permits of Foreigners}

Right to work and right to social security as both being fundamental social rights, are not identical. Unlike social security, the right of foreigners to work is an area where every state can take different actions in favour of its nationals. The idea behind the restriction of foreigners' right to work is to protect citizens' right primarily. Restriction on the employment of the foreigners is a common measure taken by almost every state to prevent unemployment of its citizens (Marhold, Franz/Friedrich, Michael, 2012: 5-26; Koch, 2015: $197 \mathrm{ff}$; Geiser, Thomas/ Müller, Roland, 2012: 99). In addition, the concern for the decrease in wages constitutes a basis for the restriction. Previously, Law dated 27.02.2003 numbered 4817 on the Work Permits of Foreigners (O.J. 
06.03.2003, 25040) and now the Law dated 28.07.2016 numbered 6735 on the International Labour Force (O.J. 13.08.2016, 29800) require foreigners to obtain permission before starting to work in Turkey either dependently or independently, unless otherwise provided in bilateral or multilateral agreements Turkey is a party to (art. 6).

According to Law No. 6735, "international labour policy shall be determined by taking into account; the mobility of the work force and regional developments as well as decisions of Migration Policies Board, the developments related to employment and business life, periodic sectoral and economic changes, development plans and programs, bilateral economic social and cultural relations as regard to foreigner's country of citizenship, international bilateral or multilateral agreements and conventions to which Turkey is party, public order, public security and public health" (art. 4).

In the legislation, foreigner is defined as the person who do not possess Turkish citizenship. According to this, foreigners are subject to permission in order to work in Turkey in principle but the foreigners who are stated to be able work without obtaining any work permit in other laws or bilateral or multilateral treaties or international conventions Turkey is party to can work or be employed without obtaining a work permit (art. 6). In some cases, a work permit exemption can be recognized to foreigners that grants the right to work without a work permit and the right to reside in Turkey. For example, foreign non-resident board member of joint-stock companies that are founded pursuant to Law No. 6102, non-executive partners of other companies, and cross-border service provider whose in-country activities not exceeding ninety days within the period of hundred and eighty days are assessed in the scope of work permit exemption (art. 13). It is essential that even those who are within the scope of the work permit exemption must document their status before the Ministry.

As for some foreigners, the conditions and procedure for obtaining permission are simplified, but they are not exempted from work permit (art. 16). For example, citizens of Turkish Republic of Northern Cyprus, citizens of the countries that are member of the European Union, persons declared by Ministry of Interior or Ministry of Foreign Affairs as of Turkish origin and those employed by their employers for a certain period in a project which is being realized in Turkey.

From the point of view of this summary info, prerequisite for foreigners to be subject to social insurance in Turkey is to have obtained work permit pursuant to Law No. 6735 and other relevant legislation. However, this does not mean that employees who works without obtaining this permit cannot be adapted to the social insurance system. As it will be examined in the following sub-heading, the principle of necessity for Turkish citizens in Turkish social insurance system is also valid for foreigners as of 06.08.2003.

\subsection{Social Insurance of Foreigners}

Until the amendment to abolished Social Insurance Law No. 506 by the Law No. 4958, short term insurance branches for the foreigners who work dependently in Turkey were obligatory while invalidity, old-age and survivors' insurance were optional (art. 3. See also Ermumcu, 2013: 60). Law No. 4958 made foreign insured subject to all social insurance branches irrespective of their wish, by introducing a fundamental change in accordance with the Convention No. 118 which our country is party to (Caniklioğlu, 2006: 685). The mandatory principle on foreigners was maintained in Law No. 5510 which entered into force on 01.10.2008. It is possible to construe from the wording of the provision stating "foreigners except those who are nationals of countries that have international social security agreements based on reciprocity principle working under service contract" that the nationals whose country of origin has a bilateral treaty with Turkey are not subject to social insurance.

Such interpretation is contrary to the essence of the right to social security, with this provision it is desired that principles in the concrete treaty provisions have priority over Law No. 5510 when implementing them on the nationals whose country has a bilateral treaty with Turkey (Tuncay/ Ekmekçi, 2017: 299). Accordingly, the principles of Law No. 5510 will be applicable to those working in Turkey by obtaining work permit who are nationals of a country which has a social security agreement with Turkey and who are not insured in that country, they are covered with all insurance branches (Sözer, 2017: 71).

\section{FOREIGNERS NOT BEING SUBJECT TO OBLIGATORY SOCIAL INSURANCE SCHEME}

As it can be seen, in the current legal system, in principle, there is no difference between the foreigners and the nationals in terms of their social insurance (Arıcl, 2015: 253), the principle of necessity in terms of all the insurance branches also applies to them. On the other hand, in accordance with the legislation on work permits for foreigners, the principle of necessity in the field of social insurance has not been sought in relation to foreigners who have been allowed to work without permission or whose conditions have been facilitated for obtaining permits. According to article 6 of the Law No. 5510 which has the title of noninsured persons, "without prejudice to the provisions of international social security agreements; persons who are sent to 
Turkey for a job by or on behalf of an organization established in a foreign country and who document to be subject to social insurance in the foreign country, and among the ones who work in Turkey on his/ her own name and account and resides abroad and are subject to the social security legislation of that country" are not deemed insured.

Work of foreigners without being subject to social insurance has been regulated here; not the opportunity of working without work permit within the scope of Law No. 6735.

There are two aspects regarding foreigners who are not insured in the provision that draw attentions. The first is that the provisions of international social security agreements have been reserved. When nationals of one of 28 countries that Turkey has signed a bilateral social security agreement work in Turkey, the provisions of the agreement will be taken into consideration with priority. The latter, different principles are foreseen between the insured who work dependently in Turkey and the ones who work independently.

The Social Security Institution issued the Circular No. 2011/43 dated 31.05 .2011 on the implementation of this provision regarding the work of foreigners without social insurance, the details of application such conditions are given here.

\subsection{The situation of foreigners who are sent by and on behalf of an organization established in a country with which Turkey has not signed a social security agreement}

Foreigners sent to work in Turkey on behalf of and by an organization established in a country are not subject to compulsory social insurance for a period of maximum 3 months with the requirement of certification indicating that such persons are subject to social insurance in foreign country (Korkusuz/ Uğur, 2015: 278). Accordingly, even though the temporary assignment of foreigner in Turkey is for period of 3 months or shorter, if he/ she cannot document that he/ she works in home country subject to social insurance or receives pension due to his/ her work is deemed obligatory insured. This requirement is related to the indispensability of social security as the basic human right. A foreigner who do not have a right to social security in his/ her home country, even though he/ she works temporarily in Turkey, cannot have a choice as to participate o Turkish social security system. An exception to this can be considered for persons with a social security right in the country of residence. Because foreigner is guaranteed for the social risks that could occur while working temporarily in Turkey in accordance with the social insurance in home country. In this way, double insurance for the same work is also prevented (Güzel/Okur/Caniklioğlu, 2016: 137; Uşan, 2009: 236).

The exemption is limited to 3 months. However, it cannot be said that a 3-month exemption is not valid for those who have been granted work permits for more than 3 months since it has been apparent that the work will last for longer than 3 months from the beginning. In this case, the Social Security Institution will register the foreigner as insured after 3 months of work (Bulut, 2011: 209).

According to the Social Security Institution circular, this 3-month exemption is one-off for each foreigner. Accordingly, this limitation cannot be evaded by coming to Turkey every time with three-month assignments. A foreigner who benefits from a three-month exemption is then directly adapted to the Turkish social insurance scheme, even if he or she comes to work for less than 3 months. But once, for example, foreigners who have worked temporarily for a period of 2 months in Turkey, when later assigned to Turkey again are considered within the exemption of 1-month period; after this 1 month, they are registered as insured. In other words, the same person may benefit from a one-time, intermittent or continuous period of three months.

In order to ensure the insurance of foreign nationals from the date of expiry of the period they are temporary, they must be notified to the Social Security Institution by the date of the expiry of the period of three months at the latest by their employers with statement of employment by submitting their foreign id number in electronical environment.

\subsection{The situation of foreigners who are sent by and on behalf of an organization established in a country with which Turkey has signed a social security agreement}

In case of a bilateral agreement between Turkey and the country where foreigners are temporarily assigned to Turkey, primarily the provisions of this agreement should be taken as basis. In practice, the importance of these agreements is the determination of the limit regarding temporariness as much longer periods in almost all of them.

First of all, the basic principle in bilateral social security agreements is that foreigners to be subject to the social security system of the country, where they work, according to the principle of territoriality (Circular of the Social Security Institution No. 2011/43). 
There is an exception for those who are temporarily assigned by their employers to the country which is party to agreement; who work in international transport, embassies, consulates, missions and similar places, who are civil and military personnel of the sending country, who work in ships carrying the flag of one of the contracting parties, or the contracting party at the ports of the country. They will not be subject to the social security legislation of the country in which they work, but to the legislation of their country, in which they are already entitled to social security. The aim here is to avoid double insurance as mentioned above. There is no aim for insecurity with regards to social security.

It is necessary for the foreigner to submit the documents listed in bilateral agreements indicating that the foreigner's social security is provided according to the legislation of home country and issued by the social security institution where the foreign is coming from. In this case, the duration of the exemption is not the period of 3 months, but the period stipulated in the concrete agreement. The striking aspect of the bilateral agreements is that both the fact that periods longer than 3 months were envisaged, and additional periods are possible at the end of such periods.

The immunity for foreigners temporarily assigned to Turkey to social security system is not limited to those are subject to compulsory social insurance in their home country. Moreover, the ones who receive pensions because of their work subject to the social security legislation of home country cannot be regarded as insured for the period of temporary assignment stated in bilateral agreement.

After the expiry of the first assignment period, the request of extension of the temporary assignment is possible via informing the insurance institution in home country by the insured or his employer and forwarding the situation to the Social Security Institution by the institution of home country. Foreigners who are eligible for the extension of their temporary assignment shall continue to be exempted from the Turkish legislation during the extension period stipulated in the agreement.

Period for temporary assignments and extension periods stipulated in bilateral agreements to which Turkey is party are listed below.

Table 1: The Practices of Temporary Assignment Pursuant to Social Security Agreements Signed with Turkey

\begin{tabular}{|c|c|c|c|}
\hline & Contract country & Temporary assignment & Length \\
\hline 1 & Britain & \multicolumn{2}{|c|}{$\begin{array}{l}\text { Legislation applies to the country in which the insured is registered as long as } \\
\text { temporary }\end{array}$} \\
\hline 2 & Germany & 5 years & 3 years \\
\hline 3 & Netherlands & 24 months & Up to the agreed period \\
\hline 4 & Belgium & 24 months & $\begin{array}{l}\text { Up to the agreed period } \\
\text { (Limited to } 60 \text { months in practice) }\end{array}$ \\
\hline 5 & Austria & 24 months & Up to the agreed period \\
\hline 6 & Switzerland & 24 months & Up to the agreed period \\
\hline 7 & France & 3 years & $\begin{array}{l}\text { Up to the agreed period } \\
\text { (Limited to } 6 \text { years in practice) }\end{array}$ \\
\hline 8 & Denmark & 12 months & Until the end of work (by agreement) \\
\hline 9 & Swedish & 12 months & 12 months \\
\hline 10 & Norway & 12 months & Up to the agreed period \\
\hline 11 & Libya & \multicolumn{2}{|c|}{ After 01.09.1985 there is permanent temporary worker practice } \\
\hline 12 & $\begin{array}{l}\text { Turkish Republic of } \\
\text { Northern Cyprus }\end{array}$ & 24 months & Up to the agreed period \\
\hline 13 & Macedonia & 24 months & Can be extended up to 60 months \\
\hline 14 & Azerbaijan & 24 months & Can be extended up to 60 months \\
\hline 15 & Romania & 24 months & Can be extended up to 60 months \\
\hline 16 & Georgia & 24 months & Can be extended up to 60 months \\
\hline 17 & Bosnia and Herzegovina & 24 months & Can be extended up to 60 months \\
\hline 18 & Canada & 24 months & Can be extended up to 60 months \\
\hline 19 & Quebec & 60 months & Up to the agreed period \\
\hline 20 & Czech Republic & 24 months & Up to the agreed period \\
\hline
\end{tabular}




\begin{tabular}{|l|l|l|l|}
\hline 21 & Albania & 24 months & Can be extended up to 60 months \\
\hline 22 & Luxembourg & 12 months & 12 months \\
\hline 23 & Italy & 12 months & Up to the agreed period \\
\hline 24 & Portugal & 12 months & Up to the agreed period \\
\hline 25 & Spain & 12 months & Up to the agreed period \\
\hline
\end{tabular}

\subsection{The situation of foreigners Coming to Turkey to Work Independently}

Another group of foreigners provided immunity from working subject to social insurance are the ones who work independently on his own behalf without being assigned by a foreign employer. Obligatory social insurance provisions are not applicable to the foreign self-employed persons without any limitations on the time, provided that they reside in a foreign country and are subject to social security legislation of that country (Güzel/Okur/Caniklioğlu, 2016: 110). Regardless of the fact that there is a bilateral social security agreement between Turkey and the country of the foreign self-employed, the exemption is not limited with a certain period unlike temporarily assigned employees. At first glance, the lack of a time limit would seem to violate the foreigners' right to social security; the requirement for residency in foreign countries indirectly demonstrates the will of temporality.

The subject of residence is regulated in Civil Code. According to the Code "residence is the place where a person intends to live permanently. A person may not have more than one residence at the same time" (art. 19). As it is seen, the principle of uniqueness of residence is essential and determining the settlement of a person who operates in different places is important in terms of legal consequences. In doctrine, could be slightly different though, residence is defined as one's main centre of life activities and relationships (Dural/ Öğüz, 2017: 189). According to this, neither workplace nor family alone is the determining factor in identifying the residence. The concrete conditions of each case should be evaluated by taking into consideration of the centre of the person's life, the duration of the time spent in such place when determining the dominant place.

Within this framework, with regards to the exception about foreign self-employed persons not being insured, when determining residence, solely official records cannot be taken as basis. Foreigners automatically obtain residence permit in Turkey by getting work permit. By solely relying on that, residence of foreigners should not be considered as Turkey; for example, it should be checked whether their family lives in abroad or in Turkey; whether foreigners travel abroad regularly or not (Sözer, 2017: 112).

Residence of the foreign self-employed abroad does not justify him/ her not being insured in Turkey alone. Since one of the reasons behind the exception regarding foreigners is to avoid double insurance, the acceptance of foreigners who are not covered with social insurance in their home country as non-insured on the ground of their residence is contrary to the Convention No. 118. For this reason, it is necessary to prove that the right of social security in the country where the foreigner resides is documented by the documents issued by that country's authority.

\section{CONCLUSION}

In terms of social security as a fundamental human right, foreignness cannot be a valid reason for different treatment. For this reason, ILO Convention No. 118 concerning Equality of Treatment of Nationals and Non-Nationals in Social Security is of great importance. The aim is to prevent the foreigners' deprivation of social security due to the fact that they work in a country other than the country of nationality. In this case, the fact that the foreigners who work subject to social insurance in a country where they are national and where they reside or who get pension due to their own work are not adapted to Turkish social insurance scheme in order to prevent double insurance does not contradict the Convention No. 118

The fact that the foreigner works in a country other than home country, where he/ she is already insured, is expected to be temporary due to the nature of the work. In Law No. 5510 temporariness for employees is limited to 3 months except for the periods in bilateral social security agreements, but there is no time limit set for self-employed persons. As long as the residence of foreigners who work in Turkey is in a country where the foreigners are national of, and they have social security rights there; elimination of time limit could be considered as de lege ferenda as it is the case for self-employed persons. Nowadays, the activities of many enterprises continue in many countries at the same time on a world scale. This requires a single-hand operation of activities in different countries. In such an organizational structure, the assignment of employees in critical positions to different countries comes up frequently. Inclusion of such a foreign employee into Turkish insurance system after expiry of the period of 3 months results in a double insurance. 


\section{REFERENCES}

Arıcı, K. (2015) Türk Sosyal Güvenlik Hukuku, Ankara, Gazi.

Bulut, M. (2011) Son Düzenlemeler Işığında Türkiye'de Bağımlı ve Bağımsız Çalışan Yabancıların Sosyal Güvenlikleri, Sicil, Vol. $23,208-215$.

Caniklioğlu, N. (2006) Sosyal Hukukun Bir Görevi Olarak Ayrımcılıktan Kaçınma ve Mağduriyetin Giderilmesi, İş Hukuku ve Sosyal Güvenlik Hukuku Türk Milli Komitesi 30. Yıl Armağanı, Ankara.

Dural, M., Öğüz, T. (2017) Türk Özel Hukuku C. Il Kişiler Hukuku, 18. Bası, İstanbul, Filiz.

Ermumcu, S. (2013). Sığınmacıların ve Mültecilerin Sosyal Güvenlik Hakları, Çalışma İlişkileri Dergisi, Vol. 4, 58-76.

Geiser, T., Müller, Roland (2012). Arbeitsrecht in Der Schweiz, Zweite Auflage. Bern.

Güzel, A., Okur, A.R., Caniklioğlu, N. (2016) Sosyal Güvenlik Hukuku, 16. Bası, İstanbul, Beta.

Koch, U. (2015). § 27 Beschäftigung ausländischer Arbeitnehmer in der Bundesrepublik Deutschland in Arbeitsrecht Handbuch, 16. neu bearbeitete Auflage, München.

Korkusuz, R., Uğur, S. (2015) Sosyal Güvenlik Hukuku, 4. Baskı, Bursa, Ekin.

Sözer, A.N. (2017) Türk Sosyal Sigortalar Hukuku, 3. Bası, İstanbul, Beta.

Tuncay, A. C., Ekmekçi, Ö. (2017) Sosyal Güvenlik Hukuku Dersleri, Yenilenmiş 19. Bası, İstanbul, Beta.

Uşan, F. (2009), Türk Sosyal Güvenlik Hukukunun Temel Esasları, 2. Bası, Ankara, Seçkin. 